\title{
"On the other hand the accused is a woman...": Women and the Death Penalty in Post-Independence Ireland
}

\section{LYNSEY BLACK}

Hannah Flynn was sentenced to death on February 27, 1924. She had been convicted of the murder of Margaret O'Sullivan, her former employer. Hannah worked for Margaret and her husband Daniel as a domestic servant, an arrangement that ended with bad feeling on both sides when Hannah was dismissed. On Easter Sunday, April 1, 1923, while Daniel was at church, Hannah returned to her former place of work, and killed 50-year-old Margaret with a hatchet. At her trial, the jury strongly recommended her to mercy, and sentence of death was subsequently commuted to penal servitude for life. Hannah spent almost two decades in Mountjoy Prison in Dublin, from where she was conditionally released on October 23, 1942 to the Good Shepherd Magdalen Laundry in Limerick. Although there is no precise date available for Hannah's eventual release from there, it is known that "a considerable time later," and at a very advanced age, she was released from the laundry to a hospital, where she died. The case of Hannah Flynn, and the use of the Good Shepherd Laundry, represents an explicitly gendered example of the death penalty regime in Ireland

Lynsey Black is an Irish Research Council Government of Ireland Postdoctoral Fellow at the Sutherland School of Law, University College Dublin <lynsey. black@ucd.ie>. She thanks Ivana Bacik, Donal Coffey, Ian O'Donnell, and Lizzie Seal for providing comment and feedback on earlier drafts of the article, as well as the anonymous reviewers for Law and History Review who gave generous and invaluable guidance on how to improve the article. She also thanks the Irish Legal History Society for a bursary received while conducting the research. 
following Independence in 1922, particularly the double-edged sword of mercy as it was experienced by condemned women. ${ }^{1}$

This article examines the cases of women sentenced to death in Ireland post-Independence, ${ }^{2}$ and argues that although women were typically the objects of formal mercy through commutation of sentence, this mercy cannot be read uncritically. Throughout, the term "mercy" is used to refer to executive clemency, demonstrated through the formal "prerogative of mercy"; however, it is acknowledged that the concept of mercy has itself been deconstructed in other accounts. ${ }^{3}$

Incorporating the concepts of chivalry and paternalism, the article argues that mercy extended to women was often an indicator of patriarchal gender relations under which women were implicitly regarded as a class apart. Mercy was applied according to a framework of chivalry: the idea that women in the criminal justice system are extended leniency because of their gender. This theory has been subjected to subsequent feminist analyses that have reconceptualized it as an exclusionary, rather than a benign, tactic. ${ }^{4}$ Mercy was also intertwined with paternalism, which posits the position of women as inferior relative to men, akin to the parent/child relationship. ${ }^{5}$ This paternalism worked to justify

1. See National Archives of Ireland (hereinafter NAI) Central Criminal Court Kerry 1923 1C-79-22; Department of Justice 18/2769A; Report of the Inter-Departmental Committee to Establish the Facts of State Involvement with the Magdalen Laundries, the "McAleese Report" (Dublin 2013). http://www.justice.ie/en/JELR/Pages/MagdalenRpt2013. Accessed 29 November 2017.

2. Ireland gained Independence from the United Kingdom in 1922. After 2 years of fighting during the War of Independence, from 1919 until 1921, during which Irish republican forces had fought British forces on Irish soil, the Anglo-Irish Treaty was signed in London in 1921. This treaty provided for the partition of Ireland, into the six counties of Northern Ireland and the twenty-six counties of the Irish Free State. Ireland became a republic in 1949, following the Republic of Ireland Act 1948. Throughout the article, references to 'Ireland' refer to the twenty-six counties that constituted, first the Irish Free State, and then the Republic of Ireland.

3. For example, Austin Sarat has argued that extension of commutation to a class of persons does not meet the formal definition of mercy, which must be an individualized function, see, Austin Sarat, Mercy on Trial: What it Means to Stop an Execution (Princeton: Princeton University Press, 2005). This argument could be made for the extension of reprieve to women as a "class" of condemned. In an Irish context, Ian O'Donnell has also categorized decisions on executive clemency according to whether they display "mercy" or "justice," see Ian O'Donnell, Justice, Mercy and Caprice: Clemency and the Death Penalty in Ireland (Oxford: Oxford University Press, 2017).

4. Ania Wilczynski, "Mad or Bad? Child-killers, Gender and the Courts," British Journal of Criminology 37 (1997): 419-36; Steven F. Shatz and Naomi R. Shatz, "Chivalry is not Dead," Berkeley Journal of Gender, Law and Justice 27 (2012): 64-112.

5. Elizabeth F. Moulds, "Chivalry and Paternalism: Disparities of Treatment in the Criminal Justice System,” Western Political Quarterly 31 (1978): 416-30. 
commutation of sentence for most women as well as lengthier periods of confinement in semipenal, religious sites.

The article offers original empirical findings, and is the first research to focus on the treatment of women sentenced to death in Ireland. There is a small but emerging body of literature on capital punishment in Independent Ireland; ${ }^{6}$ however, the existing literature does not examine gender in detail. This may be the effect of an Irish historiography that actively excludes women through its focus on political, revolutionary history, and accounts of the actions of male figures. ${ }^{7}$ The article, therefore, explores the gendered dimensions of capital punishment through the forgotten cases of condemned women, and demonstrates that comparison of the numbers of women executed versus the number of men executed reveals a partial finding only. ${ }^{8}$

Further, the article examines the role of religious sites of confinement in Ireland for reprieved women, particularly in the context of recent Irish work on the post-Independence history of "coercive confinement" for vulnerable populations, and the role of Magdalen laundries as a form of gendered control. ${ }^{9}$ The past two decades has seen a period of uncovering related to

6. Gerard O'Brien, "Capital Punishment in Ireland, 1922-1964," in Reflections on Law and History, ed. Norma M. Dawson (Dublin: Four Courts Press, 2006), 223-57; David M. Doyle and Ian O'Donnell, "The Death Penalty in Post-Independence Ireland," Journal of Legal History 33 (2012): 65-91; Ian O'Donnell and David M. Doyle, "A Family Affair? English Hangmen and a Dublin Jail," New Hibernia Review 18 (2014): 101-18. Irish historiography has traditionally been dominated by accounts of the death penalty as a tool of British oppression, or as a response to political or subversive violence in Ireland, or to violence by Irish republicans. See, for example, David Matthew Doyle, "Republicans, Martyrology, and the Death Penalty in Britain and Ireland, 1939-1990," Journal of British Studies 54 (2015): 703-22. Although this work has contributed much to understanding issues such as the changing British responses to republican violence, or the project of Irish nation building post-1922, it has meant that accounts that endeavor to embrace other perspectives are less common. As noted by Doyle and O'Donnell, in "The Death Penalty in Post-Independence Ireland," the majority of murders committed following Independence could not be characterized as political. This preoccupation with the "political" in Irish history has been noted as one factor that has prevented the development of women's history more fully, see Mary McAuliffe, "Irish Histories: Gender, Women and Sexualities," in Palgrave Advances in Irish History, ed. Katherine O'Donnell and Mary McAuliffe, (London: Palgrave, 2009), 191-212.

7. McAuliffe, "Irish Histories: Gender, Women, and Sexualities".

8. Anette Ballinger cautions against a simplistic reading of the figures. In her own research, although women were overwhelming reprieved from sentence of death, women who had been convicted of the murder of an adult were less likely to be reprieved than men. See Anette Ballinger Dead Woman Walking: Executed Women in England and Wales, 1900-1955 (Aldershot: Ashgate/Dartmouth, 2000).

9. See Eoin O'Sullivan and Ian O'Donnell, "Coercive Confinement in the Republic of Ireland," Punishment and Society 9 (2007): 27-48. This article offers a broad overview of the trends and figures for coercive confinement in the post-independence period, including 
this network of semipenal sites, and the exposure of practices of cruelty and deprivation within these institutions. This period has witnessed the recovery of stories of institutional abuse and exploitation, in cultural representations, ${ }^{10}$ as well as in academic and, sometimes reluctantly, official responses. ${ }^{11}$

Finally, although there is a substantial historiography on infanticide in Ireland, ${ }^{12}$ little has been written about women who killed adults. What does exist is fragmentary, ${ }^{13}$ or sensational. ${ }^{14}$ This article provides a profile

discussion of Magdalen laundries, mother and baby homes, psychiatric asylums, and prisons, as well as the confinement of children in reformatory and industrial schools. For accounts of the nature of gendered social control in Ireland, see James M. Smith, Ireland's Magdalen Laundries and the Nation's Architecture of Containment (Manchester: Manchester University Press, 2008); Frances Finnegan, Do Penance or Perish: A Study of Magdalen Asylums in Ireland (Piltown: Congrave Press, 2001); and Clara Fischer, "Gender, Nation, and the Politics of Shame: Magdalen Laundries and the Institutionalization of Feminine Transgression in Modern Ireland," Signs: Journal of Women in Society and Culture 41 (2016): 821-43.

10. For example, The Magdalene Sisters, a film directed by Peter Mullan, contributed significantly to the national debate on the detention of women in Magdalen laundries, see James M. Smith, "The Magdalene Sisters: Evidence, Testimony... Action?" Signs: The Journal of Women in Culture and Society 32 (2007): 431-58. Other films also, such as Philomena (2013), directed by Stephen Frears, represent the continued salience of this issue in Irish society.

11. For example, the Final Report of the Commission to Inquire into Child Abuse (Dublin: Stationery Office, 2009), called the "Ryan Report," exposed the levels of child abuse that had prevailed within the industrial and reformatory schools that were run by religious organizations. In 2013, the "McAleese Report," the final report of the Inter-Departmental Committee to Establish the Facts of the State Involvement with Magdalen Laundries, was released. In 2015, the Mother and Baby Homes Commission of Investigation was established, with the remit to examine the entry and exit of women and children from these institutions, and to further examine the living conditions, circumstances, and mortality rates within these sites. See, "Minister Reilly announces the establishment of the Commission of Investigation into Mother and Baby Homes and Certain Related Matters," Department of Children and Youth Affairs, February 19, 2015.

12. Karen M. Brennan, "'A Fine Mixture of Pity and Justice': The Criminal Justice Response to Infanticide in Ireland, 1922-1949," Law and History Review 31 (2013): 793-841; Karen M. Brennan, "Punishing Infanticide in the Irish Free State," Irish Journal of Legal Studies 3 (2013): 1-35; Cliona Rattigan, 'What Else Could I Do?': Single Mothers and Infanticide, 1900-1950 (Dublin: Irish Academic Press, 2012); Elaine Farrell, "Infanticide of the Ordinary Character: An Overview of the Crime in Ireland, 1850-1900," Irish Economic and Social History 39 (2012), 56-72; and Elaine Farrell, 'A Most Diabolical Deed': Infanticide and Irish Society, 1850-1900 (Manchester: Manchester University Press, 2013).

13. For example, some aspects of the Mamie Cadden case have been explored because of its proximity to the abortion question, see, for example, Sandra McAvoy, "Before Cadden: Abortion in Mid-Twentieth-Century Ireland," in Ireland in the 1950s: The Lost Decade, ed. Dermot Keogh, Finbarr O'Shea, and Carmel Quinlan (Cork: Mercier Press, 2004), 147-64.

14. Occasionally, such women appear in "true crime" accounts such as David M. Kiely, Bloody Women: Ireland's Female Killers (Dublin: Gill and Macmillan, 1999); and Ray Kavanagh, Mamie Cadden: Backstreet Abortionist (Cork: Mercier Press, 2006). 
of these women for the first time and examines how decision making on mercy was negotiated in such cases.

The article is structured under three headings. The first concerns the extension of formal commutation of sentence to women, and explores how mercy was often explicitly premised on gender. This section also examines the cohort of infant murders within the sample, and what made these cases different from other such cases that did not result in murder convictions. Following this, the case of Annie Walsh, the only woman executed in Independent Ireland, is explored. This case is contextualized by reference to other cases of women who killed adults to more fully explore its meanings, and the importance of gender roles is examined. Finally, post-reprieve outcomes are discussed with reference to religious institutions and Magdalen laundries. This section also incorporates a discussion of how paternalism influenced decision making on postreprieve outcomes. First however, the article overviews the methodology adopted.

\section{Researching Women Sentenced to Death}

The data used in the study were documentary sources that could provide information on women sentenced to death in Ireland. Most sources were officially generated government documents stored in the National Archives of Ireland (NAI). These included two ledgers, "Death Books," which recorded information on entry and exit from Mountjoy Prison, where condemned persons were imprisoned, as well as basic trial information. In the NAI, court records from the Dublin Commission and Central Criminal Court were consulted. These provided information on trial proceedings including, for example, depositions. For those cases in which there was an appeal, the Court of Criminal Appeal files often contained full trial transcripts. Further information was gleaned from files kept by relevant government departments. The Department of An Taoiseach archive was consulted in the NAI, and more recent files were viewed under supervision on site at the Department of An Taoiseach. ${ }^{15}$ Individual Department of Justice files on the women were consulted in the NAI, following the granting of permission from this department.

State documents were officially sanctioned accounts, created to a formalized template, intended to provide information of relevance to their original purpose. Although departmental memoranda reveal the concerns that shaped discourses on the women, they remain official accounts, framed

15. The Taoiseach is the premier of the Irish government. 
from the perspective of those in authority. ${ }^{16}$ Stephen Robertson suggests that the pitfalls of reliance on official material in historical studies of crime and deviance can be overcome. ${ }^{17}$ One approach is the inclusion of other writings on the cases, particularly press reporting, as the press represented a crucial medium of the twentieth century. ${ }^{18}$ Newspaper reports give a more complete understanding of the significance of the murder trials than do state documents alone. Contemporaneous press reporting was, therefore, examined using online databases. Press reporting provided another means of "reading" the cases and of identifying dominant narratives that played out during trials. Although press accounts cannot be accepted uncritically because of the commercial imperatives of news making, ${ }^{19}$ newspaper reporting provided a glimpse of wider public reactions to the cases as well as providing a cue for public debate in how stories were framed. Framing of events by the press was evident in the shared narratives observed between newspaper reporting and persons who wrote letters on behalf of condemned women.

In addition to the official and press discourses, the article presents public discourse on the cases, as well as the women's own voices. Public discourse was drawn from the extant letters sent by members of the public preserved within the archives. These letters were almost entirely pleas for clemency. As such, they represent one facet of discourse only. ${ }^{20}$ Public reactions oppositional to those of mercy, in contrast, were occasionally evident within police reports, ${ }^{21}$ or in newspaper commentary that recorded the reactions from within courtrooms. The voices of the

16. Dana Rabin has cautioned that we must use legal sources with some caveats in mind; namely, that researchers "must provide the historical and the legal context in which the sources were produced." Dana Rabin, "Introduction," Journal of Women's History 22 (2010): 133-35, at 134. A crucial part of this context is the inevitable power dynamics that held sway between the women in the present sample, and those in positions of authority through whom their narratives were conveyed and shaped. However, as Carolyn Strange notes "the prospect of teaching gender history without drawing on legal sources is inconceivable." Carolyn Strange, "A Case for Legal Records in Women's and Gender History," Journal of Women's History 22 (2010): 144-48, at 144.

17. Stephen Robertson, “'What's Law Got to Do with it?' Legal Records and Sexual Histories," Journal of the History of Sexuality 14 (2005): 161-85.

18. John Carter Wood, The Most Remarkable Woman in England: Poison, Celebrity and the Trials of Beatrice Pace (Manchester: Manchester University Press, 2012).

19. John Scott, A Matter of Record: Documentary Sources in Social Research (Cambridge: Polity Press, 2000).

20. Wood, The Most Remarkable Woman in England; and Lizzie Seal, "Imagined Communities and the Death Penalty in Britain, 1930-65," British Journal of Criminology 54 (2014): 908-27.

21. The police service in Ireland was renamed "An Garda Síochána" following independence. Throughout this article they are referred to as the police. 
women, too, provide perplexing questions of agency and authenticity. ${ }^{22}$ These voices are gleaned from statements, court testimony, and in petitions written while in prison. The fallacy that these are true "bottom-up" accounts is evident when one considers the rigid templates within which all these documents were produced. The voices of the women were inevitably bent toward official expectations. However, the range of sources used, including official and press accounts, and public responses as well as the voices of condemned women, serves to create a truer impression of the cases herein.

\section{Mercy by Gender}

Overwhelmingly, women sentenced to death in Ireland post-1922 were the recipients of mercy. Of the twenty-two women capitally convicted, only Annie Walsh (1925) ${ }^{23}$ was executed, whereas twenty-one had the sentence of death commuted to penal servitude for life. David M Doyle and Ian O'Donnell concluded that gender was the most striking feature of how the death penalty was applied in Ireland post-1922. ${ }^{24}$ This reflects existing research that capital punishment has been characterized as a male phenomenon historically ${ }^{25}$ and contemporaneously. ${ }^{26}$

Examination of the legal framework during this period offers one immediate explanation for the gender differential. From Independence

22. Mary Bosworth, "The Past as a Foreign Country: Some Methodological Implications of Doing Historical Criminology," British Journal of Criminology 41 (2001): 431-42; and Robertson, "'What's Law Got to Do with it?".

23. Two of the women sentenced to death were called Annie Walsh. In 1925, Annie Walsh of Limerick was executed along with Michael Talbot for the murder of her husband. In 1929, Annie Walsh of Galway was convicted along with Martin Joyce for the murder of her husband; both Walsh and Joyce were reprieved. For the sake of clarity, these cases are referred to as Annie Walsh (1925) and Annie Walsh (1929).

24. Doyle and O'Donnell, "The Death Penalty in Post-Independence Ireland".

25. For historical accounts of women and the death penalty in England and the United States see, for example, J.M. Beattie, Crime and the Courts in England, 1660-1800 (Oxford: Clarendon Press, 1986); Ballinger, Dead Woman Walking; and Victor L. Streib The Fairer Death: Executing Women in Ohio (Athens, Ohio: Ohio University Press, 2006).

26. In a United States context, see, for example, Andrea Shapiro, "Unequal before the Law: Men, Women and the Death Penalty," Journal of Gender, Social Policy and the Law 8 (2000): 428-70; and Mark D. Cunningham and Mark P. Vigen, "Death Row Characteristics, Adjustment and Confinement: A Critical Review of the Literature," Behavioural Sciences and the Law 20 (2002): 191-210. Disparity by gender continues in the modern death penalty era in the United States; for example, Justice Thurgood Marshall noted in Furman v Georgia the "overwhelming evidence that the death penalty is employed against men and not women," 408 US 238 (1972). 
until the Criminal Justice Act 1964, death was the mandatory sentence for murder, which ensured that mercy was used with greater frequency, as there was no forum in which to assess aggravating or mitigating circumstances. Further, the murder of an infant by its mother remained a capital offence in Ireland until the Infanticide Act 1949, although commutation in cases of infanticide (as it was colloquially known) had assumed the status of well-worn practice. ${ }^{27}$ Twelve of the twenty-two women had been sentenced to death for the murder of an infant; in most cases their own infant, although two women had killed the infant of a close female relative. Immediately then, there was a presumption of commutation for these women. This was evident in the case of Mary Kiernan, convicted in 1926, in a memorandum that stated: "The Department of Justice strongly recommend that sentence should not be carried out and state that it would be against all our precedents to do so." 28 In infanticide cases, therefore, the mercy shown could be interpreted as a pragmatic strategy that sought to ameliorate the harshness of the law in this area, ${ }^{29}$ and that recognized, albeit obliquely, the very real socioeconomic strains of unmarried motherhood. ${ }^{30}$ Reprieve was the only remedy against the mandatory death sentence.

As noted, there is a wealth of historiography on infanticide in Ireland. This has shown that the overwhelming majority of cases of suspected infanticide were dealt with by lesser charges, often manslaughter or concealment of birth. In Karen M Brennan's sample of 160 cases, only $28 \%$ resulted in a trial; 112 women entered a guilty plea, the majority for manslaughter or concealment. ${ }^{31}$ Of the 160 women, 124 were ultimately convicted of a lesser charge, and 26 women received a complete acquittal. ${ }^{32}$ The cases in the current sample are exceptional because they resulted in murder convictions. There are some possible explanations for this. The pregnancies all occurred outside marriage with the exception of that of Catherine Aherne, who married the father of her child while pregnant, and whose pregnancy was still characterized as a "crisis" pregnancy. However, most suspected infanticides dealt with by way of lesser charges

27. Brennan, "A Fine Mixture of Pity and Justice."

28. NAI, Department of An Taoiseach S.5195. Memorandum, November 4, 1926.

29. Karen Brennan has shown how pragmatism further influenced the eventual enactment of the Infanticide Act 1949 as well, in the desire to close the gap between law and policy/ practice, see Brennan, "A Fine Mixture of Pity and Justice".

30. Katherine O' Donovan, "The Medicalisation of Infanticide," Criminal Law Review May (1984): 259-64.

31. Brennan, "A Fine Mixture of Pity and Justice."

32. Brennan, "Punishing Infanticide in the Irish Free State." 
also involved illegitimate infants, ${ }^{33}$ so this alone cannot explain the harsh outcome in the twelve cases herein.

Incorporating the immediate context in which the death sentences were handed down is instructive. The majority of the death sentences for infanticide were passed in the late 1920s and early 1930s, a period in which the ambient discourse suggested a moral panic about the scale of illegitimacy in Ireland, something that signaled a fear of social breakdown. ${ }^{34}$ Some of this was related to a widespread belief that the familial bonds that maintained order were unravelling following the tumult of Civil War. ${ }^{35}$ Another contributing factor was the need for the new state to define itself as morally pure. This foundation myth of Ireland as "pure" was a keystone of the construction of Irish national identity in this period. ${ }^{36}$ Cases of suspected infanticide occurring during this period were, therefore, more likely to experience a harsh outcome as a form of exemplary punishment for women who became pregnant outside of marriage. That such significance is attributed to infant murder, particularly when gender roles are under scrutiny, has been noted both historically and contemporaneously. ${ }^{37}$ Broader societal concerns may, therefore, have had more to do with the harsh judgements in the cases herein. Although such cases offered pulpits for moralizing about the sanctity of infant life, this may have obscured the true cause for alarm: illegitimacy and immorality among the women of Ireland, in the early years of the newly independent state. ${ }^{38}$

33. Brennan, "A Fine Mixture of Pity and Justice." In Farrell's nineteenth century sample, she found that in $84.7 \%$ of 4,645 suspected infanticide cases, the infant was recorded as illegitimate, see Farrell, "Infanticide of the Ordinary Character".

34. Sandra McAvoy, "The Regulation of Sexuality in the Irish Free State, 1929-1935," in Medicine, Disease and the State in Ireland, 1650-1940, ed. Greta Jones and Elizabeth Malcolm (Cork: Cork University Press, 1999), 253-66; Maria Luddy, "Moral Rescue and Unmarried Mothers in Ireland in the 1920s," Women's Studies 30 (2001): 797-817; and Louise Ryan, "The Press, The Police and Prosecution: Perspectives on Infanticide in the 1920s," in Irish Women's History, ed. Diane Urquhart and Alan Hayes (Dublin: Irish Academic Press, 2004), 137-51.

35. Lindsey Earner-Byrne, "Reinforcing the Family: The Role of Gender, Morality and Sexuality in Irish Welfare Policy, 1922-1944," The History of the Family 13 (2008): 360-69.

36. Louise Ryan, Gender, Identity and the Irish Press, 1922-1937: Embodying the Nation (Lewiston: Edwin Mellen, 2002).

37. Liena Gurevich, "Parental Child Murder and Child Abuse in Anglo-American Legal System," Trauma, Violence and Abuse 11 (2010): 18-26.

38. The value placed on infant life from the nineteenth and into the early twentieth century has been questioned. Ian O'Donnell, for example, noted that as attitudes to infant life shifted, so did the corresponding criminal justice response, Ian O'Donnell, "Lethal Violence in Ireland, 1841 to 2003: Famine, Celibacy and Parental Pacification," British Journal of Criminology 45 (2005): 671-95. 
In addition to these broader dynamics, other more immediate factors in these cases marked them out for harsher punishment. In five cases, the infants had been born in county homes or other institutions, and no credible defense of natural death could be made. In these cases, the infants were typically older, and death could less easily be passed off as the disturbance of mind at childbirth, the rationale that eased the culpability of mothers who killed newborns. This was often compounded by the fact that medical staff could attest to the health of the infant on release.

Although the twelve women in the sample who were convicted of murdering infants were punished harshly when compared with the many other women who were suspected of the same deed, the act of killing the illegitimate infant itself suggested that these women had internalized societal cues surrounding the shame of illegitimacy. As noted by Brennan, rather than a negation of the maternal role, the killing of an illegitimate infant could be viewed as acceptance of prevailing norms on morality. ${ }^{39}$

Another factor that facilitated mercy was the frequent assumption that women who gave birth to illegitimate infants were weak minded. This meant that rationales for commutation could focus on the psychological vulnerability of the women rather than more considered recognition that it would be unconscionable to execute a woman convicted of infanticide. On the contrary, it was acknowledged that infanticide cases were "different," evidenced by the "working rule" within the Department of Justice, which suggested that not only should such women not be executed, but they also should not spend more than 2 years in prison. ${ }^{40}$ Pauline Prior has noted that since 1864, it had been the policy to commute the death sentences of women convicted of infant murder, ${ }^{41}$ and Elaine Farrell has found that all twenty-nine women sentenced to death for infanticide from 1850 to 1900 had their sentence commuted. ${ }^{42}$ The latter half of the nineteenth century, therefore, represented a transitional phase in public and official views on infanticide, one in which it became increasingly unacceptable that death sentences would be carried out. By the post-1922 period, death sentences were symbolic and expressive only, demonstrating what Liena Gurevich identifies as the "symbolic, boundarymaking" function of infanticide trials. ${ }^{43}$

39. Brennan, "A Fine Mixture of Pity and Justice."

40. The "working rule" was found in various files such as NAI Department of Justice file 234/2016 on Elizabeth Hannon.

41. Pauline Prior, Madness and Murder: Gender, Crime and Mental Disorder in Nineteenth-Century Ireland (Dublin/Portland, OR: Irish Academic Press, 2008).

42. Farrell, A Most Diabolical Deed.

43. Gurevich, "Parental Child Murder and Child Abuse." 
Beyond an expectation of mercy according to the legal framework and the commutation of sentence assumed in cases of infant murder, research also supports the position that mercy was extended to women qua women. Women were considered a separate "class" of offender under a gender binary that characterized them as "less than fully human, childlike, dependent, weak, and less capable than men of responsibility." 44 Writing in the United States context, Victor Streib cited "a subtle and unspoken bias" that is "implied and cultural rather than express and legal." ${ }^{45}$ In the Irish cases, however, the archives revealed that gender often provided an explicit rationale for commutation, such as in the following note by the Department of Justice on the 1927 case of Elizabeth Hannon: "The fact that the condemned person is a woman is a very relevant consideration. Women are executed in very exceptional circumstances only." 46 In the case of Mary Somerville, convicted of murdering her daughter's newborn infant in 1938, the judge outlined in his confidential notes the heinous and callous nature of the crime, before concluding, "On the other hand, the accused is a woman and, however illogical it may be, this is a matter which cannot be overlooked." 47

The extension of mercy to women because of their sex was, therefore, established practice..$^{48}$ Perhaps this was particularly true in an independent Ireland characterized by a traditional patriarchal society in which women retained an "othered" status bound up with their symbolic role as moral guardians, which lent itself to paternalistic conceptions of justice. ${ }^{49}$ Evelyn Mahon draws on Sylvia Walby's notion of private versus public patriarchy, to characterize Ireland as a private patriarchy in this period. Private patriarchy denotes a more traditional form of society in which

44. Annulla Linders and Alana van Gundy-Yoder, "Gall, Gallantry and the Gallows: Capital Punishment and the Social Construction of Gender, 1840-1920," Gender and Society 22 (2008): 324-48, at 332.

45. Streib, The Fairer Death, 132-33.

46. NAI Department of Justice 234/2016. Memorandum, December 15, 1927.

47. NAI Department of Justice 18/3110A. Letter from the judge, December 10, 1938.

48. Vivien Miller has found that rationales for commutation or leniency were explicitly grounded in considerations of gender in Florida until as late as the 1940s, Miller, “The Last Vestige of Institutionalized Sexism?' Paternalism, Equal Rights and the Death Penalty in Twentieth and Twenty-First Century Sunbelt America: The Case for Florida," Journal of American Studies 38 (2004): 391-424. The archival files on women sentenced to death in postindependence Ireland would suggest that this practice persisted beyond this date in Ireland.

49. This presented a traditional, rural, society, with women's place very much tied to the home and the domestic. This is enshrined in the Irish Constitution, at Article 41(2), which states that "The State recognises that by her life within the home, woman gives to the State a support without which the common good cannot be achieved. The State shall, therefore, endeavour to ensure that mothers shall not be obliged by economic necessity to engage in labour to the neglect of their duties in the home." See Evelyn Mahon, "Ireland: A Private Patriarchy?" Environment and Planning A 26 (1994): 1277-96. 
women are primarily caregivers resident in the home. Mahon argues that Ireland remained in this traditional stage for longer than comparable countries, and cites the low number of women in the workforce for much of the twentieth century. ${ }^{50}$ This allowed for much more explicit rationales for mercy based on gender, and this was generally reinforced by letters from members of the public. One letter writer in the case of sisters Elizabeth and Rose Edwards, sentenced to death for the murder of Elizabeth's infant in 1935, wrote that, although theoretically it was no worse to hang a woman than a man, "most people will agree that there is something peculiarly revolting in the idea of men deliberately and officially killing a woman." ${ }^{51}$ In cases less obviously sympathetic, such as the later 1929 case of Annie Walsh, who had been convicted of the murder of her husband, such inclinations were evident also. One letter writer argued: "It would be, in my deliberate \& earnest opinion, a shocking thing to hang a woman. Things have been bad enough in this land of ours and I trust, that the papers of the world will not be able to blazen forth that in this year of 1929, a woman has been hanged in Ireland." 52

Later cases also saw letter writers cite gender in mitigation, evident in the 1946 case of Agnes McAdam who had murdered her neighbor with a strychnine-laced cake. Commutation was viewed as appropriate in this case "particularly in view of the fact that the unfortunate prisoner is a woman." 53 In Agnes's case, correspondence from official quarters echoed this discourse of "mercy by gender." One senator respectfully submitted that "a woman should not be hanged," 54 while a member of the Irish Parliament wrote that "as she is a woman I trust the sentence of death will not be carried out." 55

Rationales for mercy grounded in gender were still being proposed in the 1956 case of Mamie Cadden, convicted of the murder of a woman who died while undergoing an abortion. A letter received from a constitutional scholar urged commutation to avoid "the shame and horror of bringing a human being - and a woman - to a barbarous death." 56 In this conception of humanity, it was apparent that "male" was default whereas "female" was something "other." Mamie Cadden was a "human being," but she existed also within another category, that of woman, which suggested that a male condemned would not be defined according to such an additional classification.

50. Mahon, "Ireland: A Private Patriarchy?"; and Sylvia Walby, Theorizing Patriarchy (Oxford and Cambridge, MA: Basil Blackwell, 1990).

51. "Letters to the Editor: The Edwards' Case," The Irish Times, May 18, 1935, 6.

52. NAI Department of Justice 234/2599. Letter, July 29, 1929.

53. NAI Department of Justice 18/9074A. Letter, April 8, 1946.

54. Ibid.

55. Ibid.

56. NAI Department of Justice 18/3562. Undated letter. 
The use of gender as an explicit rationale for reprieve suggests the operation of chivalry. However, the operation of chivalry within this context is complicated. It was traditionally assumed that women benefited from the chivalrous nature of a legal system dominated by men. ${ }^{57}$ However, this chivalry was partial, and was complicated by factors such as class, something that was noted by John M. Beattie when he questioned the extent to which chivalry was experienced by the female "labouring poor" in his eighteenth century sample. ${ }^{58}$ Its complexity is further highlighted by counterintuitive examples, such as Ballinger's finding that women who killed adults were less likely than men to be commuted. ${ }^{59}$ An understanding of chivalry that encompasses its more insidious meanings can account for such contradictions. Steven and Naomi Shatz explained the concept according to three tenets of: honor, rigid gender roles, and equally rigid class limits. ${ }^{60}$ Viewing chivalry through this normative lens, one can see that it is more complex than a blanket claim that women are treated more leniently. ${ }^{61}$ Chivalry is, instead, delimited by adherence to tropes of ideal womanhood, and factors of class, race and sexuality. ${ }^{62}$

\section{The Limits of Mercy}

Proving that women have a "life worth saving" has often been premised on adherence to traditional gender roles, ${ }^{63}$ and can, therefore, be viewed as a

57. This view has been espoused by writers as diverse as Otto Pollak and Freda Adler. Pollak, for example, noted the inherent "deceitfulness" of women and the favor that they received in the criminal justice system. Adler situated her use of the concept within a women's liberation framework, which suggested that women's increasing equality would dispense with the need for male criminal justice actors to "protect" women, as women committed an increasing share of the crime. Otto Pollak, The Criminality of Women (New York: AS Barnes, 1950/1961); Freda Adler, Sisters in Crime: The Rise of the New Female Criminal (New York: McGraw-Hill, 1976).

58. Beattie, Crime and the Courts in England, 439.

59. Ballinger, Dead Woman Walking.

60. Shatz and Shatz, "Chivalry is not Dead."

61. Linders and van Gundy-Yoder, "Gall, Gallantry and the Gallows."

62. See, for example, Kathryn Ann Farr, "Defeminizing and Dehumanizing Female Murderers: Depictions of Lesbians on Death Row," Women and Criminal Justice 11 (2000): 49-66; Kyra Pearson, "The Trouble with Aileen Wuornos: Feminist's 'First Serial Killer', Communication and Critical/Cultural Studies 4 (2007): 256-75; and Mary Welek Atwell, Wretched Sisters: Examining Gender and Capital Punishment, 2nd ed. (New York/Oxford: Peter Lang, 2014).

63. Jenny E Carroll, "Images of Women and Capital Sentencing Among Female Offenders: Exploring the Outer Limits of the Eighth Amendment and Articulated Theories of Justice," Texas Law Review 75 (1997): 1413-53. 
form of social control. ${ }^{64}$ Chivalry in this regard acts as a "double-edged sword," ${ }^{65}$ saving some as it condemns others. ${ }^{66}$ This section will explore how mercy was negotiated for women who killed adults, drawing particularly on the case of Annie Walsh (1925), and her failure to adhere to traditional gender roles.

Although mercy was assumed for cases of women who killed infants, commutation was less straightforward for women who killed adults. Of the ten women convicted of the murder of an adult, the pattern of killing reflects existing literature that demonstrates that when women kill, they most often kill within their family, or kill those known to them. ${ }^{67}$ Of ten women, only one killed someone who was entirely unknown to her; Mary Agnes Bernadette Daly was convicted in 1948 of the murder of an elderly woman in a church in Dublin, whom she attacked with a hammer with the assumed purpose of stealing her bags. Daly was a married woman, with a young child, and her family was in straitened financial circumstances. However, the remaining nine women killed those known to them. Five were convicted of murdering men within their family. Hannah O'Leary and Frances Cox killed brothers, both Annie Walsh (1925) and Annie Walsh (1929) killed husbands, and Jane O'Brien killed her nephew. Mary Moynihan killed the mistress of the house in which she was employed as a domestic servant, whereas Hannah Flynn murdered her former mistress. Agnes McAdam murdered her neighbour, whereas Mamie Cadden was convicted of the murder of a client, a death that occurred during an abortion procedure.

In many of these cases, commutation was less straightforward. In this vein, any discussion of mercy must grapple with the execution of Annie Walsh (1925). ${ }^{68}$ Annie Walsh was convicted on July 10, 1925 for the murder of her husband Edward at their home in County Limerick. Another man, Michael Talbot, was convicted separately for the same offense. Annie and Michael were executed in Mountjoy Prison on August 5 1925. The facts of the Annie Walsh case are as follows: On the morning of October 25, 1924, Annie Walsh appeared at the local police station, claiming that her husband Edward had been shot dead the previous night

64. Wilczynski, "Mad or Bad?"

65. Ibid., 426.

66. Elizabeth Rapaport, "Some Questions about Gender and the Death Penalty," Golden Gate University Law Review 20 (1990):501-65; Carroll, "Images of Women and Capital Sentencing"; and Jessica Salvucci, "Femininity and the Electric Chair: An Equal Protection Challenge to Texas," Boston College Third World Journal 31 (2011): 405-37.

67. Ann Jones, Women who Kill (New York: Feminist Press, 2009), 23. See also, Beattie, Crime and the Courts in England.

68. NAI Department of Justice H1004/275. 
by Michael Talbot. Annie Walsh was accompanied to her house, where Edward was found in a pool of blood. Walsh claimed that at midnight, she and her husband were awoken by Talbot, demanding entry to their home. Walsh claimed that her husband and Talbot spoke quietly in the kitchen when suddenly Talbot had struck Edward on the head, produced a revolver and shot him. Talbot was apprehended hiding in his mother's house, but when discovered, he said: "You may arrest Mrs Walsh as well as me. I did not kill him. She killed him with a hatchet. I held his hands while she killed him." 69 When the body of Edward was examined there were no bullet wounds, rather he had been killed by hatchet blows to the head. The prosecution suggested that Talbot and Walsh were having a sexual relationship. The suggested motive was related to this relationship, but also to financial gain, and it was alleged that Annie had killed her husband to obtain compensation.

However, Walsh could reasonably have expected a reprieve; a woman had not been hanged in Ireland since Mary Daly on January 9, 1903. Daly had been executed for the murder of her husband, and she had acted in concert with her lover Joseph Taylor, who was executed for the crime also, a set of facts very like those in the case of Annie Walsh. ${ }^{70}$ In the period from 1903 to independence, four women had been convicted of murder and sentenced to death. Although two of these were convicted of infant murder, two had killed adults. Sarah Anne Pearson was convicted of the murder by poisoning of her mother-in-law in 1905. It was alleged she had killed for financial gain. ${ }^{71}$ In 1915, Jane Reynolds had been convicted of the murder of her employer's wife, Rose Di Lucio. She had been convicted along with Rose's husband Angelo Di Lucio, with whom she was having an affair. ${ }^{72}$ These cases suggest a reluctance to execute women preindependence, even in atypical cases that seemed to exhibit greater reprehensibility. Prior to Mary Daly in 1903, the last woman hanged had been Margaret Sheil on April 1, 1870. Margaret was executed along with her brother Laurence, for the murder of their 30-year-old neighbor Patrick Dunne. The killing arose in the context of a dispute over land. ${ }^{73}$

Beyond these exceptions, it is the case that pre-independence was marked by the same reluctance to execute women as the post-1922 period.

69. NAI, CCC Limerick 1925 1C-90-14. Deposition of David Kenny, Police Officer.

70. "The Clonbrook Tragedy," Leinster Express, January 10, 1903, 5. NAI CRF 1902 Daly 76.

71. "Remarkable Incident: Verdict and Sentence," Examiner, March 10, 1905, 5. NAI CRF 1905 Pearson 4.

72. "Death Sentence," Examiner, November 4, 1915, 6.

73. "Trial for Murder," Examiner, March 31, 1870, 4. NAI CRF 1870 Sheil 7; CSORP 1870/6528. 
It should be noted that there was also a more general reluctance to execute in this period. Gerard O'Brien writes that even for men, from the late nineteenth century, "the Crown administration's urge to reprieve far outweighed the urge to hang."74 Both O'Brien, and Doyle and O'Donnell have argued that the death penalty under British rule was associated in the collective Irish memory with British repression of Irish nationalism. Doyle and O'Donnell claim that this ambivalence about the death penalty continued after independence, citing the failure of the newly independent state to engage an Irish hangman, preferring instead to avail of the services of English executioners, as proof of "the level of public antipathy and unease (perhaps even revulsion) towards the practice." 75 Therefore, although condemned women were often commuted because of their gender, it is important to note that this represented only one facet of decision making on reprieve.

However, it is evident that it constituted a very significant factor for consideration in cases of women. Exploring the execution of Annie Walsh (1925) in the context of comparable cases reveals that there were women considered to have committed particularly heinous murders who were reprieved. This could suggest that the extension of mercy to women qua women was arbitrary and inconsistent in its application; ${ }^{76}$ however, analysis of these other cases suggests that there were extenuating circumstances that could have governed decision making. During Annie Walsh's time in prison, a fellow inmate, Hannah O'Leary, was reprieved, whereas her brother Con was executed. ${ }^{77}$ Hannah and Con had been convicted of murdering their eldest brother Patrick in a dispute arising from inheritance. Patrick stood to inherit the family farm following his mother's death, and there was little left for Hannah and Con beyond a lifetime of work without remuneration. This, and the allegedly domineering character of Patrick, had ensured that family relations were strained. One night while he slept, Patrick was killed with an axe. The O'Leary case provided an example in which a man and a woman were convicted of the same crime and in which the woman received mercy whereas the man did not. Indeed, whereas Annie Walsh received a strong recommendation to mercy, Hannah O'Leary only received a partial recommendation. However, closer examination of the O'Leary case suggests a widespread belief that it was Con who had committed the murder, whereas Hannah's role was passive,

74. O’Brien, "Capital Punishment in Ireland," 225.

75. Doyle and O'Donnell, "The Death Penalty in Post-Independence Ireland," 69.

76. David Plater and Sue Milne, "All that's good and virtuous or depraved and abandoned in the extreme?' Capital Punishment and Mercy for Female Offenders in Colonial Australia, 1824 to 1865," University of Tasmania Law Review 33 (2014): 83-140.

77. "Five Under Death Sentences," Fermanagh Herald, July 18, 1925, 6. 
and restricted to the cleanup. This opinion as to degrees of culpability meant that it was possible to reprieve Hannah alone. ${ }^{78}$

However, the 1929 case of Annie Walsh, and the 1932 case of Jane O'Brien offer examples of women who were constructed as "evil women" by authorities, but who were reprieved nonetheless. These women had killed adult men, and were considered to possess considerable agency; therefore, their reprieves warrant closer examination. Annie Walsh (1929), in a case very similar to the earlier Walsh case and to the 1903 Mary Daly case, was convicted of murdering her husband with the participation of a man named Martin Joyce, with whom she was in a sexual relationship. Although Walsh received no recommendation to mercy, her sentence was commuted. However, this later Walsh case did present some factual differences that called for commutation, particularly because her conviction rested substantially on the evidence of children. ${ }^{79}$ In this case also, there was considerable local mobilization of support for Walsh and Joyce, and many petitions suggested that the victim had died a natural death from exposure following a drunken fall while walking over rugged terrain. Although much of this was motivated by illfeeling toward the victim in the local area, it remained persuasive, and petitions were strongly supported by local merchants, clergy, and elected officials. ${ }^{80}$

Jane O'Brien likewise garnered no sympathy for the crime of shooting her nephew dead. Jane had feared that her nephew's impending marriage would result in her eviction from the family home. Jane had moved into this home some years previously, and had assumed the duties of housekeeper. One night, as her nephew walked home from visiting friends, he was shot dead by Jane who was hiding in the hedgerows. Jane subsequently suggested that the killing was politically motivated, as the victim was a collecting agent for a political party. The killing, therefore, offered considerable evidence of premeditation and cunning. However, when considering whether her sentence should be commuted some facts presented themselves in her favor, such as the proximity of the 1932 Papal Congress, the timing of which would have rendered her execution an embarrassment. ${ }^{81}$ Additionally, Jane had been strongly recommended to

78. NAI Central Criminal Court Kerry 1923 1C-79-22; Department of Justice 18/2769A. 79. NAI Department of Justice 234/2599. Letter from judge, July 30, 1929.

80. NAI CCC Galway 1929-1931 1C-94-56-58; CCA 16/1929; Department of An Taoiseach S.5904; Department of Justice 234/2599.

81. NAI CCC Wexford 1932 1C-95-73; CCA 9/1932; Department of An Taoiseach S.8653. 
mercy based on her age and sex, and her advanced years offered a compelling factor in arguments for commutation. ${ }^{82}$

Similarly, in other cases also, extenuating circumstances were found to justify reprieve. In the 1924 case of Hannah Flynn who murdered her former employer, the facts of which are overviewed in the opening to this article, she was reprieved because of her perceived "low mentality." 83 Also in 1924, in the case of Mary Moynihan, the domestic servant who had murdered her mistress, there was sympathy expressed because of suspicions that she had acted at the urging of her mistress' husband, with whom she was having an affair. Moynihan had murdered her mistress while the victim's husband was at a fair. She had alerted neighbors with her screams, and told a story that a wild-eyed tramp had killed her mistress and attacked her before escaping. Neighborhood suspicion gradually grew, until Moynihan was herself arrested, over a year after the killing had taken place. ${ }^{84}$

Three cases occurring in the 1940 s also presented mitigating circumstances. In 1946, the commutation of Agnes McAdam for the murder of her neighbor James Finnegan by poisoning, was explained by reference to her very low intelligence and concerns about her mental state. Agnes had delivered cakes laced with strychnine to the Finnegan household, to be collected for a neighborhood social to mark the departure of two priests to the missions. It was suggested that Agnes harbored resentment that she had not been asked to help organize this event, and that her poisoning of the cakes was intended to cause minor harm only, as she assumed that the cakes would be divided into small pieces to be eaten. ${ }^{85}$ She did not anticipate that James Finnegan would eat almost an entire cake himself. There was sufficient evidence given that Agnes's mental state was quite fragile, which seemed to underpin her inexplicable behavior. ${ }^{86}$ Rationales regarding mental state were evinced in the 1948 case of Mary

82. Jane O'Brien's age was referenced in material that petitioned for clemency. One notable example is the letter from the Lord Mayor of Dublin to the Archbishop of Dublin, Dublin Diocesan Archives, Archbishop House, Archbishop Edward Byrne, AB7/Lord Mayor of Dublin.

83. NAI Dublin City Commission February 5, 1924, County Kerry; Department of Justice 18/2769A.

84. NAI CCC Cork 1924 1C-79-21; CCA 17/1924; Department of Justice 234/1744.

85. As noted by Karen M Brennan, the mens rea for murder was more expansive in the early part of the twentieth century, explaining how McAdam could be prosecuted for murder while only intending minor harm. Karen M Brennan, "Murder in the Irish Family, 1930 1945," in Law and the Family in Ireland: 1850-1950, eds. Niamh Howlin and Kevin Costello (London: Palgrave), $160-80$.

86. NAI CCC Monaghan 1946 1D-29-11; CCA 16/1946; Department of An Taoiseach S.13804; Department of Justice 18/9074A. 
Agnes Bernadette Daly also, who, as noted, had killed an elderly woman in a Dublin church. The atypicality of Daly's violence, suggested abnormality of mind, and some accounts suggested that she was of a nervous and highly strung disposition. Daly drew further sympathy as a respectable married woman, and mother to a young child, particularly as the murder could be framed as an attempt to provide for her family, which was facing eviction. Additionally, arguments were made that drew on the lingering effects of childbirth, as Daly had given birth 6 months before the murder. ${ }^{87}$ Frances Cox, who was convicted in 1949 of the murder by poisoning of her brother, was also considered to be laboring under mental strain related to childbirth. Frances had murdered her brother Richard with strychnine. However, some weeks before the murder, she had killed her illegitimate newborn infant. Arguments were made in private that she had not fully recovered from the effects of giving birth. At trial, her actions were presented as a cynical attempt to ensure the family farm would pass to her; something that she feared would not happen if her Protestant Church of Ireland family discovered that she was in a clandestine relationship with a local Catholic farmer. ${ }^{88}$ Behind the scenes however, her assumed disturbance of mind following her recent childbirth made commutation a more palatable decision for authorities.

In the final case in the sample, the capital conviction of Mamie Cadden in 1956 for the murder of a woman who died as a result of an abortion procedure - although there was considerable public hostility expressed toward Cadden because of her devalued reputation as an abortionist - the conviction rested on the antiquated legal doctrine of constructive malice. ${ }^{89}$ Cadden had accepted the victim Helen O'Reilly, as a client in need of a service, and no harm had been intended. Cadden had once practiced as a nurse, although she had been removed from the register for previous similar offenses. Although there was significant official and public horror toward Cadden's business, the conviction operated as expressive

87. NAI CCC Unknown Counties 1949 1D-50-42; CCA 68/1948; Department of An Taoiseach S.14430; Department of Justice 170/7622.

88. NAI CCC Dublin 1949 1D/29/7; CCA 72/1949; Department of An Taoiseach S.14689; Department of Justice 18/11757.

89. The doctrine of constructive malice ensured that as death resulted from the commission of a felony, an attempt to procure a miscarriage under s58 of the Offences Against the Person Act 1861, the mens rea, or malice, implicit in this crime was transferred to the resulting death. The doctrine was abolished in England and Wales under the Homicide Act 1957, and abolished in Ireland until the Criminal Justice Act 1964. The doctrine had come up particularly in relation to deaths resulting from abortion. In Cadden's case, it was argued as grounds in favor of commutation, NAI Department of An Taoiseach S16116, Telegram 4 January 1957. 
punishment only, and the flimsy legal means by which it was secured made commutation more likely. ${ }^{90}$

It is, therefore, difficult to say with certainty why Annie Walsh was executed, when so many others were reprieved. The small numbers of women sentenced to death in this period, and the very few women who were executed, renders any conclusions necessarily tentative. Gerard O'Brien cites the judge's failure to endorse the jury recommendation, together with the prevailing atmosphere of violence following the Civil War, and the legacy of punitive Victorian-era judges. From comparison of the case of Annie Walsh with that of Mary Daly in 1903, and Margaret Sheil in 1870, some substantive features also seem to be instructive. The status of the victim, namely that he was an adult man, and the dominance of the woman, particularly in relation to the wielding of influence over a younger man, are common features across these cases, compounded by Walsh's deviant sexuality. This was exacerbated by the failure to find mitigating circumstances. However, it should be noted that failure to elaborate any extenuating circumstances itself represents unwillingness to commute. Analysis of cases of women executed in other jurisdictions throws up some commonality too, in the greater likelihood that killers of men will be executed, and that women shown to be sexually agentic and deviant will be executed, as well as those women who are constructed beyond respectable femininity. ${ }^{91}$

The arguments that motivated decision making in Walsh's case are lost, and, therefore, it cannot be said with certainty why Annie Walsh alone was not extended the clemency that had become the expectation in cases of women sentenced to death. It may have been instrumental that there was little in the way of public campaigning for reprieve, something noted in press reporting: "Little, if any, public interest was aroused in the execution which took place this morning. Beyond the presence of a few policemen and newspaper reporters outside the entrance to the prison, there was nothing else to indicate the grim scene which was about to be enacted within its

90. NAI CCA 36/1956; Department of An Taoiseach S.16116; Department of Justice 18/ 3562.

91. Atwell,. Wretched Sisters; and Ballinger, Dead Woman Walking. The English case of Edith Thompson, executed in 1923, is illustrative of the detrimental influence that sexuality can wield. Thompson was executed for the murder of her husband, who had been stabbed by her lover Freddie Bywaters. In this case, although there was no conclusive proof that Thompson had foreknowledge of her lover's intentions to kill, her sexual dalliance was crucial in securing her conviction and execution. See, Lizzie Seal, Capital Punishment in Twentieth-Century Britain: Audience, Justice, Memory (London: Routledge, 2014); and Lucy Bland, "The Trials and Tribulations of Edith Thompson: The Capital Crime of Sexual Incitement in 1920s England," Journal of British Studies 47 (2008): 624-48. 
walls." 92 There were also no letters appealing for clemency within the extant archives on Walsh. However, the lack of interest may have derived from an expectation that Walsh would be reprieved. ${ }^{93}$

\section{Exploring Gender Roles in the Case of Annie Walsh (1925)}

There were, therefore, factors that rendered Walsh's crime more heinous that were firmly rooted in gender role expectations. Walsh was characterized as the dominant partner in the plot to murder her husband, with Talbot as her dupe. It was alleged throughout the trial that Walsh killed her husband for the compensation she would receive. The use of subheadings in press reporting presented a means of "reading" the event, and these made frequent reference to Walsh as deceitful and mercenary, evident in the examples of "Would Kill Ned," "Telling Lies," and "Waiting for Cheque." 94

The references to Annie Walsh's age, she was 31, also painted her as dominant. Annie's husband Edward was described in one headline as an "aged man done to death." 95 Rendering the victim weak suggested the dominance of the perpetrator. The co-convicted Talbot, in contrast, was described as "only 23." 96 During Talbot's trial, he was characterized as powerless and referred to as "a servant boy." 97 In contrast, prosecution counsel emphasized the dominance of Annie Walsh: "The case for the prosecution was that Talbot went to the house that night, and with the assistance of a vigorous woman, murdered this poor man Walsh." 98 Talbot's defense counsel forcibly underlined this point also, suggesting that he had been "dominated by a passionate woman." 99 The sexual aspect of the crime, which inevitably informed her construction as dominant, further rendered Walsh's an abject and unsympathetic case. Her framing as dominant suggested that Annie Walsh had seduced Michael Talbot, engaged in an extramarital sexual relationship with him, and then manipulated him in her plan to murder her husband.

92. "Co. Limerick Murder: Man and Woman Executed," Irish Examiner, August 6, 1925, 6.

93. It is evident, too, that some newspapers were "hedging their bets" in case a last minute reprieve was granted. "Irish Woman to be Hanged To-day," Irish Independent, August 5, $1925,5$.

94. "Limerick Murder," Freeman's Journal, November 18, 1924, 6; and "Hatchet Crime," Freeman's Journal, November 13, 1924, 5.

95. "Fedamore Horror," Limerick Leader, October 27, 1924, 3.

96. "Double Execution," Irish Independent, August 6, 1925, 8.

97. "To Be Hanged: Brutal County Limerick Murder," Examiner, July 10, 1925, 7.

98. Ibid.

99. "She Killed Him," The Irish Times, July 10, 1925, 6. 
Annie Walsh's dominance was referenced in the 1932 case of Jane O'Brien as well. As noted, her crime of shooting her nephew dead was considered particularly callous, and presented the real fear that she would be hanged. Petitioners, therefore, felt the need to distinguish her case from that of the only other woman executed in recent memory: "In the case of Mrs Walsh, it was a murder committed under brutal circumstances in which the woman took the leading part, and in which her paramour over whom she had control was also sentenced to death, and her reprieve would have meant the reprieve of the man in the case." 100 A letter from Jane O'Brien's solicitor reinforced this point: "Mrs Walsh.... was convicted of a particularly brutal murder - one of savage brutality. We think it would have been very difficult to have reprieved her and hanged her lover, so we presume that the Executive Council at that time felt they could not let one off and hang the other."101

Therefore, although paternalistic rationales for commutation directed decision making in many cases, such discourses were not mobilized in the case of Walsh. The section has outlined how Walsh's gender nonconformity, typified by her sexual infidelity and dominance, rendered her crime of husband murder even more heinous. Equally, Walsh's dominance can also be viewed as masculine and agentic, and as Callahan notes, "If a woman behaved in a masculine fashion, masculine punishment must have seemed reasonable to judges." 102 It is difficult to isolate the notion of punishment of gender nonconformity from the severity of punishment that can accrue to women who are overburdened with masculine agency. Instead, these strands exist as unavoidable corollaries, to mark out certain women as less deserving of mercy. Finally, the case of Annie Walsh and Michael Talbot may offer an opportunity to consider how gender played a role in decision making toward male condemned. One significant limitation of the research herein is the lack of a male comparator. The death penalty regime is no less gendered for cases of condemned men. However, without fuller analysis of the narratives employed in men's cases, it is not clear how such cases were framed differently than cases of women. To date, there is no Irish research on how death sentences were negotiated for condemned men. ${ }^{103}$ An approach that acknowledges the gendered nature of this phenomenon is needed. As articulated in the abovementioned

100. NAI Department of Justice 18/2737A. Petition on behalf of Jane O‘Brien.

101. NAI Department of Justice 18/2737A. Letter from MJ O'Connor and Company Solicitors, Wexford, 13 July 1932.

102. Kitty Callahan, "Women Who Kill: An Analysis of Cases in Late-Eighteenth- and Early-Nineteenth-Century London," Journal of Social History 46 (2013): 1013-38, at 1030.

103. However, a forthcoming text from Ian O'Donnell should begin to address this gap, see O'Donnell, Justice, Mercy and Caprice. 
petition on behalf of Jane O'Brien, however, it was viewed as unthinkable to pardon Walsh and execute Talbot, considering her role as chief instigator. Equally however, it is true that a decision was made not to commute either Walsh or Talbot. The case may, therefore, suggest how gender might apply as a further condemnation in cases of men sentenced to death, something on which there is very little research.

\section{The Aftermath of Mercy}

Processes of mercy continued after official commutation of a death sentence. Following reprieve, the twenty-one women whose sentences had been commuted continued to experience informal negotiation of mercy. This section highlights the role of paternalism in the release of women from prison and their confinement in semipenal religious sites. ${ }^{104}$ Paternalism is understood as legal protections extended to women derived from their "inferior" and "different" status. It offers "a useful theoretical construct" through which to explore asymmetrical power relations. ${ }^{105}$

Doyle and O'Donnell cite the median figure of 3 and a half years spent in prison by reprieved women, whereas reprieved men spent 7 and a half years in prison. ${ }^{106}$ Although most reprieved women spent little time in prison, there was significant variation, evident in the cases of Hannah Flynn and Hannah O'Leary, who spent more than 18 years and 17 years in prison respectively. The Department of Justice commented on Hannah Flynn's imprisonment that there was "no record of any cases since 1879 of women serving such a long time, the longest range from 7 to 14

104. Elizabeth F. Moulds, "Chivalry and Paternalism: Disparities of Treatment in the Criminal Justice System,” Western Political Quarterly 31 (1978) 416-30. In an Irish context, Karen Brennan writes that paternalism was evident in official responses to cases of suspected infanticide; she argues that in this context, paternalism was distinct from humanitarian considerations. Instead, this paternalism "reflected the patriarchal nature of Irish society and the gender ideologies of public officials." Brennan, "A Fine Mixture of Pity and Justice," 834. Vivien Miller has argued similarly, in relation to the death penalty regime in Florida. Miller argues that to execute women on the same terms as men would have undermined the differentiation between the sexes that prevailed in society. Invoking the paternalism that suffused the ideology of Southern states, Miller states that the more lenient treatment for women convicted of murder in twentieth century Florida cemented their inferior position. Miller, "The last vestige of institutionalized sexism?"

105. Kathy Davis, "Paternalism under the Microscope," in Gender and Discourse: The Power of Talk, Vol. XXX, ed. Alexandra Dundas Todd and Sue Fischer, (New York: Ablex Books, 1988), 23.

106. Doyle and O'Donnell, "The Death Penalty in Post-Independence Ireland”. 
years." 107 However, although Flynn's case was unusual, it was not entirely isolated, evident in the similar length of time served by O'Leary, and in the upper figure of 14 years cited.

There is also significant variation according to whether the victim was an adult or an infant. Comparing the periods of time spent in prison by women convicted of killing an adult, with that for those who killed infants, it emerges that women who killed infants spent shorter periods of time in prison. Whereas Kate Owens spent almost 5 and a half years in prison, most spent considerably less. Kate Owens's lengthier imprisonment reflects her status as a "persistent offender" who had previously been convicted of concealment of birth. Shorter periods of imprisonment for infanticide cases were provided for officially; a Department of Justice memorandum specified that persons serving a sentence of penal servitude for life should not be considered for release until they had served the equivalent of 20 years, but this included an exception for infanticide. A further guideline specified, "As a working rule in infanticide cases I think that the mother convicted should be kept in prison for a period of two years and then placed in a home." 108 However, despite this, there was no certainty as to how long such women should spend in prison. This was demonstrated by the secretary at the Department of Justice who noted, in the case of Christina Russell, that because of the age of the infant at death she "should suffer five full years imprisonment before we consider releasing her either wholly or to a Home." 109 The discretionary and informal decision making facilitated the disparity of imprisonment length within the sample.

Once infanticide is removed, the contrast between imprisonment periods experienced by men and women is less marked. The periods of time spent in prison for women convicted of killing an adult were more substantial than the median figure of 3 and a half years. Recalculating the median imprisonment lengths demonstrates that women who murdered an infant spent a median period of 2 years and 3 months in prison, whereas women who murdered adults spent a median period of 6 years and 7 months in prison, much closer to the figure for male reprieved. ${ }^{110}$

However, it remains the case that most women spent relatively short periods of time in prison. The view of prison as unsuitable for women

107. NAI Department of Justice 18/2769A. Note, November 6, 1936.

108. This "working rule" was found in various files within the archives; for example, NAI Department of Justice 234/2016 (Elizabeth Hannon); and Department of Justice 234/2603 (Catherine Aherne). "Home" in this context referred to the network of religious-run institutions across Ireland.

109. NAI Department of Justice 234/3332. Letter from Stephen Roche, November 17, 1933.

110. Doyle and O’Donnell, "The Death Penalty in Post-Independence Ireland". 
goes to the heart of paternalism in the criminal justice system; ${ }^{111}$ the article suggests that an avowedly paternalistic approach to deviant women shaped the responses to offending women in Ireland post-1922. There were very few women held within the officially approved sites of the criminal justice system for much of this period; the numbers of women in prison fell in the decades that followed independence. ${ }^{12}$ Christina Quinlan notes that numbers fell through the twentieth century to the extent that women's prisons were closed, and there was a daily average figure of twenty-four women in prison in 1974. ${ }^{113}$ The women who were in prison in these decades were often petty but persistent offenders, ${ }^{114}$ presenting a very different profile to that of women who had been reprieved from death.

However, consideration of imprisonment length alone fails to capture the extent of confinement experienced by reprieved women. A philosophy of paternalism envisages prison as harmful for women, and proposes alternative sites of confinement. ${ }^{115}$ Although the periods of time spent in prison by women who killed an adult ranged from less than 2 years, in the case of Mamie Cadden, to more than 18 and a half years, for Hannah Flynn, both figures are misleading. Cadden had been transferred to the Central Criminal Lunatic Asylum in 1958, where she died the following year. Hannah Flynn was conditionally discharged from prison to a religious-run institution, where she remained for approximately three decades. Similarly, the infanticide cases also provide a misleading figure. Although Elizabeth Doran spent 51 days in prison, she was certified as insane post-conviction and transferred to the Central Criminal Lunatic Asylum at Dundrum on July 24, 1926. In total, she spent 4 years and 11 months in some form of confinement.

The treatment of death-sentenced women in post-independence Ireland must therefore be contextualized within the state's reliance on sites of semipenal coercive confinement. ${ }^{116}$ Drawing on extant and accessible archives, academic literature has demonstrated the extensive use of carceral institutions to control "unruly" populations; in 1951, 1\% of the Irish population was coercively confined. ${ }^{117}$ Mary Raftery and Eoin O'Sullivan

111. Moulds, "Chivalry and Paternalism".

112. Christina Quinlan, Inside: Ireland's Women's Prisons, Past and Present (Dublin: Irish Academic Press, 2011); and Rogan M. Prison Policy in Ireland: Politics, PenalWelfarism and Political Imprisonment (London: Routledge, 2011).

113. Quinlan, Inside: Ireland's Women's Prisons.

114. Ibid.

115. Moulds, "Chivalry and Paternalism."

116. Mary Raftery and Eoin O'Sullivan, Suffer the Little Children: The Inside Story of Ireland's Industrial Schools (Dublin: New Island, 1999); Smith, Ireland's Magdalen Laundries; and Eoin O'Sullivan and Ian O'Donnell, Coercive Confinement in Ireland: Patients, Prisoners and Penitents (Manchester: Manchester University Press, 2012).

117. O'Sullivan and O'Donnell, Coercive Confinement in the Republic of Ireland. 
argued that the post-independence Irish solution to welfare provision was institutional, in many cases in partnership with religious orders; a system that afforded an economic means of providing basic care, while affording the Catholic Church a central position within Irish society. ${ }^{118}$ As O'Sullivan and O'Donnell note, the concept of the "carceral archipelago" is not new; ${ }^{119}$ however, it provides an alternative means of thinking about punishment in Ireland. I argue that reprieved women were subject to the same processes of institutionalization as those identified by O'Sullivan and O'Donnell involving the cooperation of the state, the church, and the family. ${ }^{120}$ These processes offer some explanation for the treatment of vulnerable persons in Ireland in this period, particularly women and children. ${ }^{121}$

Of twenty-one reprieved women, eleven were conditionally discharged from prison to religious institutions, the majority to Magdalen laundries. Clara Fischer notes that the existence of these sites marked the creation of a gendered system of social control that relied on an acceptance of women's bodies as sites of shame. ${ }^{122}$ Table 1 lists the institutions to which the eleven women were sent. ${ }^{123}$ In addition to these eleven, Kate Owens was discharged from prison to a paid situation with the Sisters of Charity, St. Monica's. ${ }^{124}$ It should be noted here, that one limitation of the research is the lack of comparable data on the post-reprieve outcomes for men. Although it is known that reprieved men spent, on average, a longer time in prison, little is known about their post-prison experience. Whereas a gendered post-prison institutional network existed for women, there was not a similar network for men. Ian O'Donnell has suggested many men were encouraged to emigrate after release. ${ }^{125}$

118. Raftery and O'Sullivan, Suffer the Little Children.

119. Michel Foucault, Discipline and Punish: The Birth of the Prison (London: Penguin, 1979/1991). Foucault's concept of the "carceral continuum" encompassed sites like the religious-run institutions in which many reprieved women were held.

120. Smith, "The Magdalene Sisters."

121. Raftery and O'Sullivan, Suffer the Little Children.

122. Fischer, "Gender, Nation, and the Politics of Shame."

123. Of these institutions, only Henrietta Street and the Bethany Home have not been officially classified as Magdalen laundries, although this was a point of criticism of the "McAleese Report" with regard to Henrietta Street. The Bethany Home has subsequently also become the subject of further investigations regarding the mistreatment of women and children.

124. NAI Department of Justice 18/6678A. Kate Owens's discharge from prison on these grounds may represent the further informal coercive power of such disposals. It may have been unlikely that she would have been released otherwise.

125. Ian O'Donnell, "Deflecting the Law from its Course: Capital Punishment and Clemency in Ireland, 1923-1990" (32nd Hugh M Fitzpatrick Lecture in Legal Bibliography, Bar Library of Ireland, December 1, 2015). 
Table 1. Institutions to which reprieved women were transferred

\begin{tabular}{|c|c|c|}
\hline Name & Institution & $\begin{array}{c}\text { Year of } \\
\text { Entry }\end{array}$ \\
\hline $\begin{array}{l}\text { Deborah } \\
\text { Sullivan }\end{array}$ & Sisters of Charity, Henrietta Street, Dublin & 1929 \\
\hline $\begin{array}{l}\text { Elizabeth } \\
\text { Hannon }\end{array}$ & $\begin{array}{l}\text { Our Lady of Charity Refuge, High Park, } \\
\text { Drumcondra, Dublin }\end{array}$ & 1930 \\
\hline $\begin{array}{l}\text { Mary Anne } \\
\text { Keane }\end{array}$ & Sisters of Charity, Donnybrook, Dublin & 1930 \\
\hline Mary Moynihan & Sisters of Charity, Henrietta Street, Dublin & 1930 \\
\hline Margaret Finn & Sisters of Charity, Donnybrook, Dublin & 1933 \\
\hline $\begin{array}{l}\text { Elizabeth } \\
\text { Edwards }\end{array}$ & Sisters of Charity, Henrietta Street, Dublin & 1937 \\
\hline Mary Somerville & Bethany Home, Rathgar, Dublin & 1940 \\
\hline Jane O'Brien & Sisters of Charity, Henrietta Street, Dublin & 1941 \\
\hline Hannah Flynn & Good Shepherd Convent, Limerick & 1942 \\
\hline Hannah O'Leary & St. Vincent's, Mary's Road, Cork & 1942 \\
\hline Agnes McAdam & Good Shepherd Convent, New Ross, Wexford & 1949 \\
\hline
\end{tabular}

The cases of capitally convicted women must be situated within an Irish context before their treatment can be understood. Paternalism has historically been enmeshed with concerns for the protection of women and girls, and has often equated risk with a need to protect female sexuality. ${ }^{126}$ Within a national context of narrowly imagined gender roles, with heavy emphasis on morality, the death penalty existed as a further means of defining and delimiting acceptable womanhood. The post-1922 Irish state sought to construct its nationhood on certain symbolic foundations, one of which was the purity of Irish womanhood. ${ }^{127}$ Louise Ryan has noted

126. In an Irish context, Raftery and O'Sullivan noted that young women and girls were often placed in Magdalen laundries or industrial schools because they were viewed as being at risk of immorality, regardless of whether any wrongdoing or offense had occurred. See Raftery and O'Sullivan, Suffer the Little Children.

127. For discussions of ideas of the "Irish woman" in this period see, for example, Margaret Ward, Unmanageable Revolutionaries: Women and Irish Nationalism (Dublin: Pluto Press, 1995); Sandra McAvoy, "The Regulation of Sexuality in the Irish Free State, 1929-1935," in Medicine, Disease and the State in Ireland, 1650-1940, ed. Greta Jones and Elizabeth Malcolm (Cork: Cork University Press, 1999), 253-66; and Barbara O'Connor, "Colleens and Comely Maidens: Representing and Performing Irish Femininity in the Nineteenth and Twentieth Centuries," in Ireland in Focus: Film, Photograph and Popular Culture, ed. Eoin Flannery and Michael Griffin (New York: Syracuse University Press, 2009) 144-65. For a succinct overview of Irish political approaches to sexuality, reproduction, and abortion from historical to contemporary practices, see Christina 
of this time that "Cultural nationalism, political conservatism and the power of the Catholic Church combined together to create the circumstances in which women's bodies became the contested site of national good and national evil." ${ }^{28}$ Magdalen laundries, therefore, offered a location to which women's bodies, which signified "national evil," could be removed. Their function in this regard extended far beyond the cases of reprieved women, or even women convicted of any crime, encompassing many iterations of female "deviance," from fallen women who had had multiple pregnancies outside of marriage, to women and girls considered unruly or sexually "at risk." Following the Criminal Justice Act 1960, Magdalen laundries were used as sites to which women could be sent as an alternative to prison; however, prior to this legislation, they had served this purpose for many years. ${ }^{129}$ Brennan notes that Magdalen laundries were a frequent site of confinement for women convicted of infanticiderelated offenses. ${ }^{130}$ There is some evidence of a shift in the function of such institutions over time; James M. Smith argued that Magdalen laundries became more carceral from the late nineteenth century on, ${ }^{131}$ whereas Clíona Rattigan noted their transformation into alternatives to prison for infanticide cases post-independence. ${ }^{132}$

Of the eleven women, many had expressed their willingness to enter religious institutions, or "homes," in the petitions that they wrote in prison. However, for some women who had initially asked to be released to their family, their petitions adapted over time to reflect realistic expectations. In May 1942, Hannah Flynn had petitioned that she would "be willing to accept any terms with regard to Licence to finish my 20 years if I were allowed out." 133 Discussions of what was to be done with Flynn include the note on her file, "she herself does not want to go to a convent." 134 In October, Hannah relented, stating in a petition, "I am willing to go to the Good Shepherd Convent, Limerick and remain there."135

The procedure of conditional discharge that saw women released to religious-run institutions was vague. A special form of license was issued

Quinlan, "Policing Women's Bodies in an Illiberal Society: The Case of Ireland," Women and Criminal Justice 27 (2017): 51-72.

128. Ryan, Gender, Identity and the Irish Press, 12.

129. Smith, Ireland's Magdalen Laundries.

130. Brennan, "A Fine Mixture of Pity and Justice."

131. Smith, Ireland's Magdalen Laundries.

132. Rattigan, 'What else could I do?'

133. NAI Department of Justice 18/2769A. Petition, May 12, 1942.

134. Ibid., Report, July 27, 1942.

135. Ibid., Petition, 8 October 1942. 
to the women, which was conditional on entry to a "home."136 The procedures were ad hoc and a lacuna existed whereby women could not be compelled to remain. The government's only solution should women leave was to cancel the license and return them to prison; however, this mechanism had not been availed of for decades. ${ }^{137}$ The absence of official coercive power to direct that women remain in the institutions is because the licences were not formally worded as conditional on entry to a "home"; to achieve this, each amended licence would have to be brought before both houses of the Oireachtas, or Parliament, which the Department considered "undesirable," in order "to discourage the insertion of harsh, tyrannical or absurd conditions." 138 This lack of formal coercive power did not diminish the unofficial coercive capacity of conditional release, which was noted by the Department in their comment that women were "unlikely" to leave. Women's institutionalization was, therefore, not subject to scrutiny, something that contributed to an effective practice of indeterminate sentencing. This represented a form of social death, as many of the women who entered religious-run institutions simply disappeared.

These institutions, particularly the Magdalen laundries, present an iteration of the existence of a stark example of a "system of institutionalization that was especially punitive, pervasive, and persistent." 139 Recently, the emergence of survivors' accounts of life inside the laundries has illuminated their punitive nature. ${ }^{140}$ Maeve O'Rourke has noted that the laundries were operated "for profit," and that the women were "imprisoned and forced to carry out unpaid labour for the commercial benefit" of the religious congregations who ran them. ${ }^{141} \mathrm{O}$ 'Rourke highlights the catalogue of psychological abuse and physical exploitation, as well as the enforced silence and denial of education that characterized the experience of confinement. Many survivor accounts describe how on entry to a laundry, the women's real names were replaced with new names, as well as mentioning the practice of cropping women's hair on admission. In the research herein, although nothing definite can be said about the eventual release dates for many of the women, it is known that the women who spent longest in a religious institution were those who had been placed in laundries. Within these sites, contact with the outside world was

136. Issued under the Penal Servitude Acts 1853 to 1891.

137. NAI Department of Justice 234/2590. Minutes, October 29, 1929.

138. NAI Department of Justice 234/1744.

139. Fischer, "Gender, Nation, and the Politics of Shame," 829.

140. Contemporaneous accounts of Magdalen laundries have also been published, see for example, Halliday Sutherland, "Irish Journey," in Coercive Confinement in Ireland, 80-91.

141. Maeve O'Rourke, "Ireland's Magdalene Laundries and the State's Duty to Protect," Hibernian Law Journal 10 (2011): 200-237, at 200. 
restricted or nonexistent. ${ }^{142}$ This is typified by the survivor accounts, which detail how the women escaped from laundries only to be returned by police. ${ }^{143}$ The acknowledgement of the character of Magdalen laundries eventually led to a state apology in February 2013. Therefore, although these religious institutions presented an ostensibly welfarist function, they were experienced by women as punitive sites, and in many ways represented a more punitive alternative to imprisonment.

When periods of time spent within these religious-run institutions are taken into consideration, the length of confinement increases. Whereas some women spent very little time in these institutions, others remained until their deaths. Consideration of time spent in religious institutions following conditional discharge from prison presents an alternative interpretation of the punishment of reprieved women. For many of the women, the exact time spent coercively confined is unknown. Although conditional discharge to religious institutions was recorded by the Department of Justice, the eventual release of the women (for those who were released) was not. Further information was gleaned from the McAleese Report, ${ }^{144}$ which presented three anonymized case studies that were identified as three women in the sample. From matching these, it is known that two of the twenty-one reprieved women within the sample died in a religious institution; as noted in the opening case study, Hannah Flynn was eventually released from a laundry to hospital, where she died some years later. However, unlike the statement of median lengths of imprisonment, which can be broken down according to male versus female, and according to victim status, the lack of access to the religious archives means that no average figures of confinement post-commutation can be calculated. However, as noted, it is evident that the women who spent the longest periods of time in such institutions were those in Magdalen laundries.

\section{Paternalism and Decision Making}

Decisions on release from prison, and from religious institutions for these eleven women, were bound up with considerations of: class and respectability, family support, and individual agency and capacity, as well as sexuality. For some, there were few alternatives to conditional discharge to a

142. Smith, Ireland's Magdalen Laundries.

143. Justice for Magdalenes (JFM) (compiled by James M Smith, Maeve O'Rourke, and Claire McGettrick), "State Involvement in the Magdalene Laundries: JFM's Principal Submission to the Interdepartmental Committee" (Justice for Magdalenes, February 16, 2013). https://www.magdalenelaundries.com/State_Involvement_in the_Magdalene Laundries_public.pdf. Accessed 29 November 2017.

144. The "McAleese Report." 
religious institution; the brother and sister-in-law of Agnes McAdam, for example, made it clear that she was not welcome should she attempt to return home. In a state that had scant welfare supports beyond its network of institutions, ${ }^{145}$ release from prison to an institution like a Magdalen laundry offered some guarantee of shelter. However, for some women there were alternatives. In the case of Elizabeth and Rose Edwards, Elizabeth was conditionally discharged to Henrietta Street convent, while her younger sister was released to her family. Elizabeth was the mother of the infant victim in this case, and her extended confinement could be interpreted as a further punishment over and above that experienced by her sister. In certain cases, such as that of Hannah Flynn, decisions were made about the unsuitability of the home to which she would be released, which led to her life-long detention, first in prison and then in a laundry. Likewise, for Margaret Finn, she remained in a laundry until her death because her family was considered unsuitable because of their poverty and intergenerational illegitimacy. In some cases, such as that of Elizabeth Hannon, her perceived "weak-mindedness" proved decisive in the decision to conditionally discharge her to a laundry, and in the further decisions that refused her permission to ever leave this institution. However, even Mary Moynihan, who had considerable family support and who could also lay claim to a family that was relatively respectable, spent time in the Henrietta Street convent before her eventual release to a paid situation with the religious congregation. This may have related to her sexual dalliance with the husband of the victim.

Women who were released from prison without spending time in a religious institution include Mary Kiernan and Christina Russell, both of whom had killed illegitimate infants, as well as Annie Walsh (1929) and Frances Cox, who were known to have engaged in sexual relationships outside marriage. Examination of which women were released in this manner therefore throws up some unpredictability. However, considerations of family status and future prospects played a role; both Walsh and Cox had considerable agency, and had the support of influential champions, such as Frances Cox whose release was petitioned for by Major Acton of the Salvation Army. Similarly, despite their illegitimate pregnancies, both Kiernan and Russell could be viewed as coming from relatively nonproblematic family backgrounds.

The treatment of women post-reprieve was, therefore, governed by gender roles rooted in paternalism. Paternalism, although ostensibly benevolent, can have adverse consequences for women, such as when it is used

145. Finola Kennedy, Cottage to Creche: Family Change in Ireland (Dublin: Institute of Public Administration, 2001). 
to justify lengthier periods in detention for women. Although paternalism has occasioned favorable outcomes for individual women in the criminal justice system, ${ }^{146}$ it has been defined by feminists as ultimately harmful, because the protection afforded women is based on their presumed inferiority; women are, therefore, less than fully adult, when "adult" is synonymous with "male." 147 This paternalism spared women's lives, but it cannot be read uncritically as leniency. Detailed research into the post-reprieve trajectories of men would help to illuminate further the extent to which this was a gendered approach, experienced solely by women, and how men's experiences suggest an equally gendered, and divergent, response.

The drive to remove women from prison to sites of semipenal confinement was premised on the removal of such women from criminogenic influences; as noted, the typical population of women's prisons was of petty but persistent offenders. ${ }^{148}$ One Roman Catholic chaplain noted that Mary Moynihan was "forced in prison to associate with women, many of whom are a little mad, and nearly all completely bad." ${ }^{149}$ As Elizabeth Moulds notes, this is fundamental to the operation of paternalism in the criminal justice system. ${ }^{150}$ The secretary at the Department of Justice proposed a plan for the institutionalization of female convicts beyond the prison, stating "I have often considered an Act to authorise their detention... not as punishment but as persons needing shelter and protection." 151 This encapsulates the concept of paternalism, which is at once ostensibly well intentioned and controlling. Paternalism is, therefore, a gender management strategy related to the wielding of power over women "for their own good." Gurevich argued that paternalism concerns the exercise of positive power; however, this article demonstrates that, at least within the context of Ireland in this period as a private patriarchal state, paternalism also justified coercive power. ${ }^{152}$ Kathy Davis, too, considered paternalism to be "a concept of power which combines the element of benevolence with the elements of dominance and subordination."153 This conception of paternalism accords with the findings herein in its

146. As noted by Smart, in Carol Smart, Women, Crime and Criminology (London: Routledge and Kegan Paul, 1977).

147. Moulds, "Chivalry and Paternalism."

148. Quinlan, Inside: Ireland's Women's Prisons.

149. NAI Department of Justice 234/1744. Letter to the Minister for Justice, November 6, 1927.

150. Moulds, "Chivalry and Paternalism."

151. NAI Department of Justice 18/2770A. Memorandum to Minister for Justice, May 20 1940.

152. Liena Gurevich, "Patriarchy? Paternalism? Motherhood Discourses in Trials against Children," Sociological Perspectives 51 (2008): 515-39.

153. Davis, "Paternalism under the Microscope," 23. 
position that coercion and benevolence are not mutually exclusive. The use of religious institutions, particularly Magdalen laundries, is situated within an Irish negotiation of mercy for reprieved women, and was underpinned by paternalistic rationales prevalent in the traditional patriarchal society of the time, which justified the lengthy confinement of reprieved women in religious institutions. This use of extrapenal sites as gendered judicial disposals for reprieved women is something that must be investigated further in other jurisdictions. ${ }^{154}$

\section{Conclusion}

The death penalty in independent Ireland was subject to highly gendered processes. Both death sentences and post-reprieve outcomes were experienced differentially by women, and this difference has typically been characterized as mercy. However, close examination complicates a straightforward notion of mercy. Women were a separate "class" of offenders, and an alternative identity was carved out whereby they were understood first as "women" and only peripherally as "murderers." This is evident in the rationales proposed to justify commutation, in which gender was persuasive. The rhetoric was that women should not be hanged. These arguments were grounded in chivalrous ideologies that justified the use of special protections for women as a category. In a majority of cases, such discourses were mobilized to ensure reprieve. However, the case of Annie Walsh in 1925, and a review of the cases of the few women executed in the decades preceding independence, demonstrate that although paternalistic rationales of protection were fairly generalized, they were not absolute. The very small numbers of women who were executed allows for tentative interpretations only, but these executions were made intelligible by reference to sets of facts viewed as particularly reprehensible, such as the killing of an adult man, dominance, and sexual infidelity.

Exploring the cases through the lens of a particular time and place suggests that the paternalistic treatment of death-sentenced women in Ireland, and the uses of coercive confinement, were firmly wedded to the gender ideologies of a historically specific Irish moment. The traditional, patriarchal structure of Irish society represented a moment in time in which a new state forged its reliance on institutional confinement and on the

154. Anette Ballinger, "Feminist Research, State Power and Executed Women: The Case of Louie Calvert," in Escape Routes: Contemporary Perspectives on Life after Punishment, ed. Stephen Farrall, Mike Hough, Shadd Maruna, and Richard Sparks (London: Routledge/ Cavendish, 2011), 107-33. 
infrastructure of religious organizations, particularly in the provision of social welfare. Under this national regime, women became "contested sites," on which patriotic hopes and fears could be played out. ${ }^{155}$ The private patriarchy that prevailed in these decades, therefore, ensured explicitly gendered rationales for reprieve as well as paternalistic motivations for the treatment of reprieved women and the confinement of these women in extrapenal, religious sites.

The gender ideologies that operated throughout the Irish criminal justice system continued to operate beyond decisions on commutation. Mercy was not experienced as a single instance. Reprieved women, instead, experienced an ongoing negotiation of mercy, consisting of countless small decisions, made over decades. In this way, gender ideologies could condemn women to lifelong confinement just as surely as they could save a woman's life in the first place. Through an evaluation of gender and the death penalty from a position often decades following reprieve, the significance of the gendered death penalty processes becomes stark. Beyond the disparity in the numbers of women and men executed, the pervasive influence of gender on punishment can be further understood through the more mundane decisions that governed life post-reprieve. The article suggests that referencing the mercy that women experience in the criminal justice system, if such statements are not investigated further, can create a partial and unsatisfying interpretation of the interaction of gender ideologies and punishment. Incorporating a more expansive scope of inquiry instead shows that women were judged on scales of punishment so specific to their gender that it created a system, and an infrastructure, that amounted to a parallel death penalty regime from that experienced by men, one informed by paternalism and deeply ingrained in the Irish post-independence context.

155. Ryan, Gender, Identity and the Irish Press, 12. 